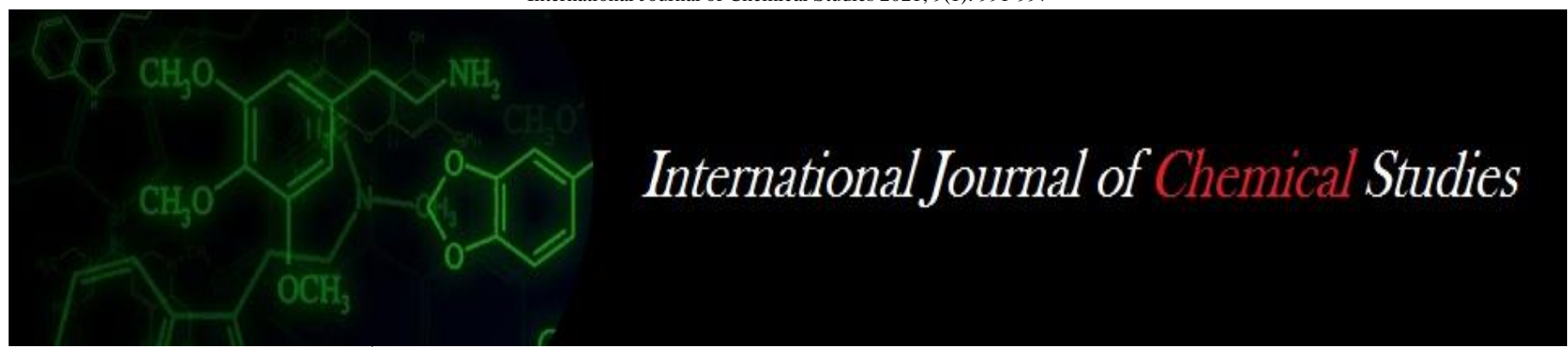

P-ISSN: 2349-8528

E-ISSN: 2321-4902

www.chemijournal.com

IJCS 2021; 9(1): 991-997

(C) 2021 IJCS

Received: 24-11-2020

Accepted: 28-12-2020

Ruchi Chauhan

Department of Agricultural

Biotechnology, Department of

Seed technology Department of

Agricultural Biotechnology

CSK HP KV Agriculture

University, Palampur, Kangra,

Himachal Pradesh, India

Rakesh Kumar Kapila

Department of Agricultural

Biotechnology, Department of

Seed technology Department of

Agricultural Biotechnology

CSK HP KV Agriculture

University, Palampur, Kangra,

Himachal Pradesh, India

Rajeev Rathour

Department of Agricultural

Biotechnology, Department of

Seed technology Department of

Agricultural Biotechnology

CSK HP KV Agriculture

University, Palampur, Kangra,

Himachal Pradesh, India

\section{Introgression of rice blast and bacterial leaf blight resistance genes into HPR2143 rice variety through marker assisted selection and Anther culture}

\author{
Ruchi Chauhan, Rakesh Kumar Kapila and Rajeev Rathour
}

DOI: https://doi.org/10.22271/chemi.2021.v9.i1n.11355

\begin{abstract}
The use of resistant rice cultivars is the most proficient way to overcome rice blast and bacterial blight diseases in rice. Cultivars, however, experience a rapid breakdown in their resistance, predominantly due to the advent of new pathotypes. Therefore, for durable resistance, it is important to combine multiple genes that impart resistance to more than one pathotypes into one genetic background. Foreground selection of $\mathrm{BC}_{2} \mathrm{~F}_{2}$ plants of two crosses (HPR2143/DHMAS164 and HPR2143/PB1) was done to detect the presence of blast resistance genes i.e. Pita and Pi9 in these plants. Plants homozygous for gene Pita were screened by a pair of gene specific markers YL87/155 (coupling dominant) and YL87/183 (repulsion dominant). Likewise, homozygous positive plants for gene $\mathrm{Pi} 9$ were identified using the codominant marker Pi9STS-1. For bacterial blight (BLB) resistance genes, $\mathrm{BC}_{2} \mathrm{~F}_{2}$ plants of two crosses (HPR2143/IRBB54 and HPR2143/PR114) were screened for genes Xa21 and Xa38 using gene-derived markers BLB248 and Oso4g53050-1, respectively. Anther culture of developed $\mathrm{F}_{1} \mathrm{~s}$ was attempted for fixation of genes.
\end{abstract}

Keywords: Rice, Pi9, Pita, Xa21, Xa38

\section{Introduction}

Rice (Oryza Sativa L.) is the substantial food crop of Southeast Asia where almost half the world's population reside (Mohiuddin et al., 2014) ${ }^{[17]}$. Approximately $92 \%$ of rice is grown and consumed by Asian population, which constitute 55\% of the world population (Wilson and Talbot, 2009) ${ }^{[32]}$. It has been estimated that rice production must increase to approximately 136 million tonnes by 2050 in order to keep pace with the rising population (Anonymous, 2015) ${ }^{[2]}$. Although rice production has accelerated almost threefold over the past three decades (Christopher, 2002) ${ }^{[4]}$, continued increase in yield productivity and number of varieties is necessary to meet the growing demand of the global population (De-Filippis, 2014) ${ }^{[9]}$. However, one of the primary restraints in achieving this target is the increased manifestation of certain pests and diseases (Yugander et al., 2018) ${ }^{[35]}$.

In spite of continuous progression in rice breeding programmes, significant yield losses from diseases still prevail in rice. Of the most destructive diseases that abstain rice production, blast caused by the fungus Magnaporthe grisea (anamorph: Pyricularia grisea) ranks first because of its severity under favourable conditions. Another important disease of rice is bacterial blight caused by Xanthomonas oryzae pv. oryzae which is an endemic constraint to rice production worldwide (Narayanan et al., 2004) ${ }^{[19]}$. The utilization of resistant (R) genes and germplasm are efficient ways to combat these devastating diseases (Ni et al., 2015) ${ }^{[20]}$.

The improvement of rice varieties for resistance to the diseases that are predominant and eradicative is necessary for the sustainability of rice grain yields (Pinta et al., 2013) ${ }^{[22]}$. Breeding for host-plant resistance is regarded as the most frugal and eco-friendly strategy for pest and disease management of crop plants. Due to high levels of variability in the disease populations in growing areas, past attempts to achieve varietal resistance to blast and bacterial leaf blight disease have been disappointing (Sreewongchai et al., 2010) ${ }^{[30]}$.

The utilization of DNA markers in plant breeding programme is known as marker assisted selection (MAS) (Akhtar et al., 2010) ${ }^{[1]}$. The application of molecular markers can speed up
Corresponding Author:

Ruchi Chauhan

Department of Agricultural

Biotechnology, Department of

Seed technology Department of Agricultural Biotechnology

CSK HP KV Agriculture

University, Palampur, Kangra,

Himachal Pradesh, India 
resistance breeding efforts, since segregating plants can be identified by molecular marker alleles instead of their phenotypes and introgression of multiple resistance genes or gene pyramiding can be monitored easily in a population (Sundaram et al., 2014) [31]. Marker assisted selection provides a potential solution to some of the problems that cannot be resolved by traditional breeding (Miah et al., 2013) [16]. DNA marker technology has contributed immensely to genetic advancement through the selection of desirable characteristics, such as resistance to disease. Rice has become a model plant for research in the field of breeding and genetics. Quantum leap in genomics and molecular biology, proteomics and metabolics has opened new channels to expend innovative approaches to rice breeding. Foreground selection has become an integral element of germplasm improvement. Molecular markers have their implication in trait improvement by tagging large number of genes/QTLs for different traits with them (Khush, 2013) ${ }^{[14]}$. Owing to genetic linkage, DNA markers can be used to mark the existence of allelic variation in the genes underlying these traits (Collard and Mackill, 2008) ${ }^{[10]}$.

Anther culture, an innovative method for accelerating the generation of homozygous doubled haploids (DH), can be used to hasten the varietal improvement programmes in rice (Herawati et al., 2010) ${ }^{[12]}$. Many desirable traits such as disease resistance, high grain weight, dwarf plant type and abiotic stress tolerance were introgressed into rice breeding population by means of anther culture (Sengsai et al., 2007) [27]. Double haploidy (DH) technology thus offered a technique to shorten breeding cycles and and increase genetic gain (Ren et al., 2017) ${ }^{[26]}$. In the light of the above, the present study was undertaken to exploit molecular marker technologies and anther culture for the efficient management of rice blast and bacterial leaf blight through the introgression of important rice blast (Pita and Pi9) and bacterial leaf blight (Xa21 and $\mathrm{Xa38}$ ) resistance genes into a popular variety, HPR2143 rice.

\section{Materials and Methods}

As resistance gene donors to rice blast, the rice genotypes DHMAS164 and PB1 consisting of the Pita and Pi9 genes were used respectively, while genotypes IRBB54 and PR114 constituting genes $\mathrm{Xa} 21$ and $\mathrm{Xa38}$ respectively were used as resistance gene donors against bacterial blight. However, rice cv. HPR2143 was used as a recipient parent. Previously established crosses between recurrent parent HPR2143 and resistance donors and their further backcrosses $\left(\mathrm{BC}_{2} \mathrm{~F}_{2}\right)$ developed through an ongoing programme in the Department of Agricultural Biotechnology, CSKHPKV Palampur at that time were used as an initial material for the research (Table 1).

The seeds of selected elite $\mathrm{BC}_{2} \mathrm{~F}_{2}$ progenies of four crosses, HPR2143/DHMAS164 (Pita), HPR2143/PB1 (Pi9), HPR2143/IRBB54 (Xa21) and HPR2143/PR114 (Xa38) were sown in small separate plots (in nursery beds) in the cage house of the Department of Agricultural Biotechnology, CSK
HPKV Palampur.

Table 1: Details of the material used in the present study

\begin{tabular}{|c|c|c|c|}
\hline Cross & Gene & $\begin{array}{l}\text { Designated Plant } \\
\text { Number }\end{array}$ & Generation \\
\hline $\begin{array}{l}\text { HPR2143 } \times \\
\text { DHMAS164 }\end{array}$ & Pita & $1-41$ & $\mathrm{BC}_{2} \mathrm{~F}_{2}$ \\
\hline HPR2143 × PB-I & $P i 9$ & $42-83$ & $\mathrm{BC}_{2} \mathrm{~F}_{2}$ \\
\hline HPR2143 × IRBB54 & $X a 21$ & $84-125$ & $\mathrm{BC}_{2} \mathrm{~F}_{2}$ \\
\hline HPR $2143 \times$ PR114 & Xa38 & $126-167$ & $\mathrm{BC}_{2} \mathrm{~F}_{2}$ \\
\hline
\end{tabular}

\section{Research Methodology}

Foreground selection was carried out to select homozygous plants for genes Pita, Pi9, Xa21 and Xa38 using specific gene-derived markers. The selected gene-positive homozygous plants for the Pita and Pi9 genes were crossed to obtain sufficient $F_{1}$ seeds $(\approx 100)$ in order to combine two blast resistance genes $(\mathrm{Pita}+\mathrm{Pi} 9)$. In the similar manner, to combine two bacterial leaf blight resistance genes $(X a 21+X a 38)$, the selected gene positive homozygous plants for genes Xa21 and Xa38 were crossed to obtain adequate seeds $(\approx 100)$. Sufficient number of $F_{1}$ plants of crosses HPR2143/PB1 $($ Pi9) $\times$ HPR2143/DHMAS164 (Pita) and HPR2143/IRBB54 (Xa21) × HPR 2143/PR114 (Xa38) was raised under controlled conditions. Anthers of abovementioned crosses were used to induce androgenic doubled haploids following previously standardised protocols in our lab (Chopra, 2006) ${ }^{[7]}$.

\section{i. Marker aided foreground selection}

Genomic DNA of 167 plants of aforementioned four crosses was extracted from fresh leaves at an appropriate stage, using CTAB method (Murray and Thompson, 1980) ${ }^{[18]}$. The PCR amplification was performed using gene-derived STS primers. Foreground selection for the blast resistance gene Pita was conducted using the gene derived markers, YL87/155 (coupling dominant) and YL87/183 (repulsion dominant) (Table 2). Likewise, homozygous positive plants for $P i 9$ gene were screened using Pi9STS-1 marker (Table 3). The plants having bacterial blight resistant genes $\mathrm{Xa} 21$ and $\mathrm{Xa} 38$ were identified using the gene-derived markers Blb248 and Os04g53050-1, respectively (Table 4. For DNA amplification, a reaction mixture of $12.5 \mu \mathrm{l}$ volume was prepared using $7.05 \mu \mathrm{l}$ of PCR water, $2.0 \mu 1$ template DNA (20 ng), $1.25 \mu \mathrm{l} 10 \mathrm{X}$ buffer $(10 \mathrm{mM}), 1.0 \mu \mathrm{l} \mathrm{dNTP} \operatorname{mix}(0.5$ $\mathrm{mM}$ each of dATP, dGTP, dCTP, dTTP), $0.5 \mu$ f forward primer $(5 \mathrm{pM}), 0.5 \mu 1$ reverse primer $(5 \mathrm{pM})$ and $0.2 \mu 1$ Taq polymerase $(3 \mathrm{U} / \mu \mathrm{l})$. The amplification was carried out in Veriti 96 wells Thermal Cycler (Applied Biosystem, CA, USA) following PCR amplification profiles given in Tables 24.

Hybridization among backcross derivatives containing single genes was attempted in order to pyramid 2 genes for each disease. Anthers of aforementioned crosses were used to induce androgenic doubled haploids following already standardised protocols in our lab (Chopra, 2006) ${ }^{[7]}$.

Table 2 PCR profile used for amplification of YL87/155 and YL87/183 markers linked to gene, Pita

\begin{tabular}{|c|c|c|c|c|}
\hline \multirow{2}{*}{ Steps } & \multicolumn{2}{|c|}{ Temperature profile } & & Cycles \\
\cline { 2 - 3 } & YL87/155 & YL87/183 & & \\
\hline Initial Denaturation & $94^{\circ} \mathrm{C}$ for 3 minutes & $94^{\circ} \mathrm{C}$ for 3 minutes & & \\
\hline Denaturation & $94^{\circ} \mathrm{C}$ for 45 seconds & $94^{\circ} \mathrm{C}$ for 45 seconds \\
\hline Annealing & $55^{\circ} \mathrm{C}$ for 45 seconds & $55^{\circ} \mathrm{C}$ for 45 seconds \\
\hline Extension & $72^{\circ} \mathrm{C}$ for 1 minute & $72^{\circ} \mathrm{C}$ for 1 minute \\
\hline Final extension & $72^{\circ} \mathrm{C}$ for 7 minutes & $72^{\circ} \mathrm{C}$ for 7 minutes & & \\
\hline
\end{tabular}


Table 3 PCR profile used for amplification of Pi9STS-1 marker linked to the gene, $P i 9$

\begin{tabular}{|c|c|c|c|}
\hline \multirow{2}{*}{ Steps } & Temperature profile & & Cycles \\
\hline & Pi9STS-1 & & \\
\hline Initial Denaturation & $94^{\circ} \mathrm{C}$ for 5 minutes & & \\
\hline Denaturation & $94{ }^{\circ} \mathrm{C}$ for 1 minute & & \multirow{4}{*}{35 cycles } \\
\hline Annealing & $59^{\circ} \mathrm{C}$ for 1 minute & & \\
\hline Extension & $72^{\circ} \mathrm{C}$ for 1.30 minutes & & \\
\hline Final extension & $72^{\circ} \mathrm{C}$ for 5 minutes & & \\
\hline
\end{tabular}

Table 4: PCR profile used for amplification of Os04g53050-1 and Blb248 markers linked to genes, Xa38 and Xa21, respectively

\begin{tabular}{|c|c|c|c|c|}
\hline \multirow{2}{*}{ Steps } & \multicolumn{2}{|c|}{ Temperature profile } & & Cycles \\
\cline { 2 - 3 } & Os04g53050-1 & Blb248 & & \\
\hline Initial Denaturation & $94^{\circ} \mathrm{C}$ for 5 minutes & $94^{\circ} \mathrm{C}$ for 5 minutes & & \\
\hline Denaturation & $94^{\circ} \mathrm{C}$ for 1 minute & $94^{\circ} \mathrm{C}$ for 30 seconds & & \\
\hline Annealing & $56^{\circ} \mathrm{C}$ for 1 minute & $55^{\circ} \mathrm{C}$ for 1 minute & & \multirow{3}{*}{35 cycles } \\
\hline Extension & $72^{\circ} \mathrm{C}$ for 1 minute & $72^{\circ} \mathrm{C}$ for 1 minute & & \\
\hline Final extension & $72^{\circ} \mathrm{C}$ for 5 minutes & $72^{\circ} \mathrm{C}$ for 5 minutes & & \\
\hline
\end{tabular}

ii. Anther culture of $F_{1}$ progenies to achieve fixing of two genes each in doubled haploids: The $\mathrm{F}_{1} \mathrm{~s}$ of two crosses i.e. $($ Pita + Pi9) and cross $2(X a 21+X a 38)$ developed at the cage house of the Department of Agricultural Biotechnology, CSKHPKV were used as the source of anthers for developing blast and bacterial leaf blight resistant doubled haploids, respectively. Optimal fertilizers and plant protection measures were adopted to raise healthy plants.

\section{Results and Discussion}

i. Foreground selection for Pita gene homozygotes: For cross 1 (HPR2143 X DHMAS164), the gene specific markers
YL87/155 (coupling dominant) and YL87/183 (repulsion dominant) were used for foreground selection. In case of YL87/183 marker, out of 41 plants screened, bands were present in 25 plants including progeny number 3,7 to 13,15 to 17,19 to $21,23,24,26$ to $29,34,35,38,40$ and 41 (Fig. 1, lanes represented by blue arrows) which indicated the absence of Pita gene in these plants. The remaining 16 plants $(1,2,4$, $5,6,14,18,22,25,30,31,32,33,36,37$, and 39; lanes indicated by red arrows in Fig. 1) in which bands were absent therefore had the probability of having Pita gene. In order to confirm the existence of the Pita gene in these 16 plants, the coupling phase marker YL87/155 was amplified on the same set of plants. Further foreground selection using this marker indicated presence of desired amplified bands in 5 progenies having progeny nos. 6, 30, 36, 37 and 39 confirming the presence of Pita gene in these progenies (Fig. 2; lanes represented by red arrows.

Two markers, YL155/YL87 and YL183/YL87 belong to the functional marker class. However, both are dominant and cannot discriminate homozygous genotypes from heterozygous ones. Thus, we detected the same individuals using one marker, and then followed with the other to identify homozygous Pita plants. In literature, earlier workers have also used these two markers to infer homozygosity of the plants for Pita gene (Xiao et al., 2016) ${ }^{[34]}$. In the present case, out of a total population of 41 plants, five were assessed to be homozygous for Pita gene using YL87/183 and YL87/155 markers. This frequency is comparatively lower than the expected 25 per cent. This may be due to small size of the sampled plants and differential development accounting for the distorted ratio.

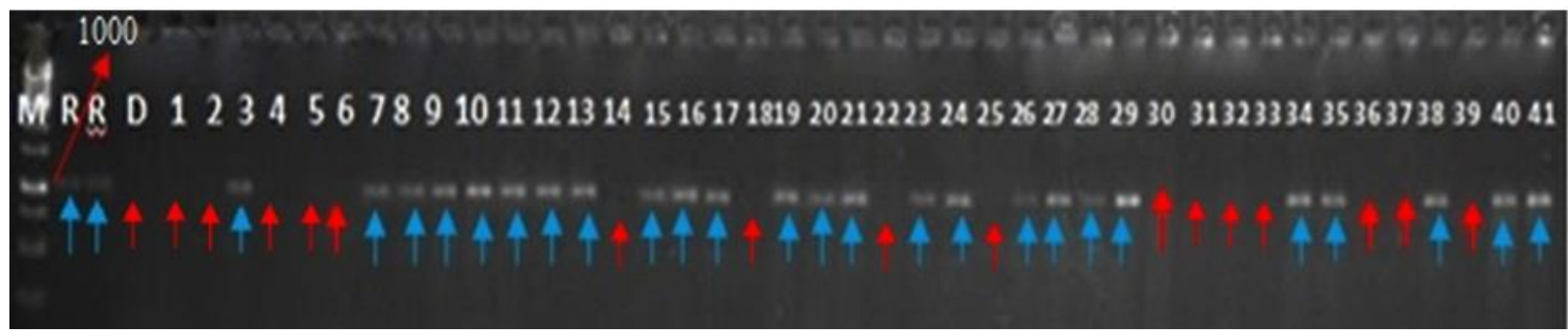

Fig 1: Foreground selection for blast resistance gene Pita in $41 \mathrm{BC}_{2} \mathrm{~F}_{2}$ progenies of cross HPR2143×DHMAS164 using repulsion phase marker YL87/183 Lanes in the gel from left represent M: Molecular weight marker (1kb ladder), R: recurrent parent (HPR2143), D: donor parent (DHMAS164) and 1-41 BC2 $F_{2}$ progenies of HPR2143/DHMAS164 cross. PCR products were resolved on 1.5 per cent agarose and stained with ethidium bromide

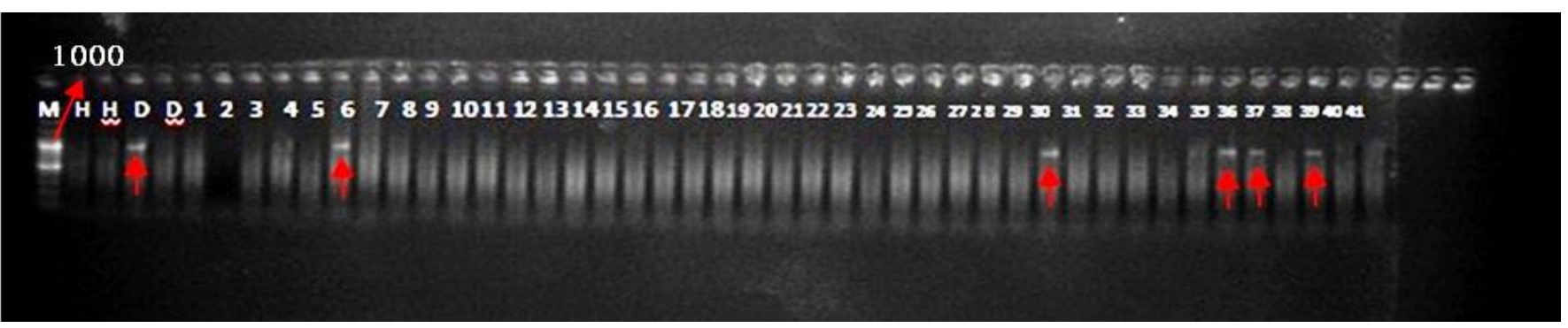

Fig 2: Foreground selection for blast resistance gene Pita in $41 \mathrm{BC}_{2} \mathrm{~F}_{2}$ progenies of cross HPR2143×DHMAS164 using dominant phase marker

YL87/155 Lanes in the gel from left represent M: Molecular weight marker (1kb ladder), H: recurrent parent (HPR2143), D: donor parent (DHMAS164) and 1-41 BC $\mathrm{C}_{2} \mathrm{~F}_{2}$ progenies of HPR2143/DHMAS164 cross. PCR products were resolved on 1.5 per cent Agarose and stained with ethidium bromide

\section{ii. Foreground selection for Pi9 gene homozygotes}

In cross 2 (HPR2143 X PB1), out of 42 plants screened with Pi9STS-1 marker linked to gene Pi9, 20 progenies (42 to 46, $51,61,63,64,66,67,69,72,74$ to 79 and 81 ) were found to be homozygous positives for Pi9 gene (Fig. 3; Lanes indicated by red arrows). The Pi9 broad-spectrum blast resistance gene derived from the wild tetraploid species, Oryza minuta (Sitch et al., 1989) ${ }^{[29]}$ is most successful 
against the blast races prevalent in various parts of India (Khanna et al., 2015; Rathour et al., 2011) [15, 24], which makes it an ideal choice for use in breeding programme. The gene-derived marker Nbs2Pi-9 and SSR markers linked to the allelic gene $\mathrm{Piz}$ (Fjellstrom et al., 2006) ${ }^{[10]}$ have been widely used in MAS of the Pi9 gene. However, the Pi9-linked SSR markers can sometimes result in misidentification of genepositive plants due to the recombination between marker and gene. Considering the relevance of $P i 9$ gene and shortcomings of the currently available markers for this gene, Rathour et al. (2016) ${ }^{[25]}$ developed co-dominant gene-derived markers for efficient marker-assisted selection of the Pi9 gene by making use of the publicly available DNA sequence of the cloned $P i 9$ gene. Of the three STS markers designed by Rathour et al. (2016) ${ }^{[25]}$, the marker Pi9STS-1 showed a fragment size of $1073 \mathrm{bp}$ in $\mathrm{Pi}-9$ containing line Pusa 1637 and $1185 \mathrm{bp}$ in PB1, while Pi9STS-2 amplified a 753 bp fragment in Pusa 1637 and 844 bp in PB1.

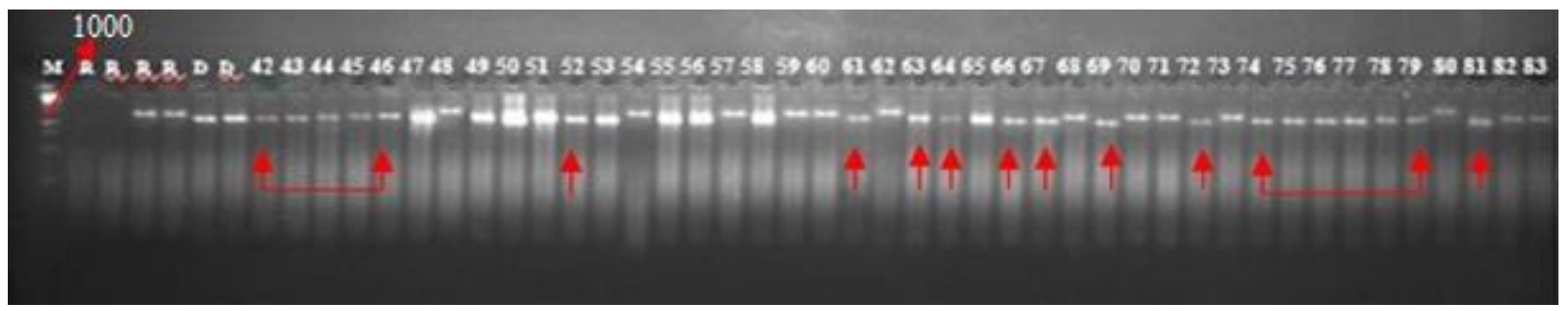

Fig 3: Foreground selection for blast resistance gene $P i 9$ in $42 \mathrm{BC}_{2} \mathrm{~F}_{2}$ progenies of cross HPR $2143 \times \mathrm{PB}-1$ using Pi9STS-1 Lanes in the gel from left represent M: Molecular weight marker (1 kb ladder), R: recurrent parent (HPR2143), D: donor parent (DHMAS164) and 42-83: BC $\mathrm{C}_{2}$ progenies of the cross, HPR 2143 X PB-1. PCR products were resolved on 2.5 per cent Agarose and stained with ethidium bromide

\section{iii. Foreground selection for $\mathrm{Xa21}$ gene homozygotes}

In cross 3 (HPR2143 X IRBB54), out of 42 plants screened using marker $B L B$ 248, 12 (86, 91, 96, 97, 98, 106, 110, 111, $112,115,123$ and 125) were found to be homozygous positives (lanes represented by red arrows in Fig. 4), 23 were homozygous negatives $(84,85,89,92,93$ to $95,100,101,103$ to 105,107 to $109,113,114,116,117,120$ to 122 and 124 , represented by blue arrows) and 7 were heterozygous $(87,88$, $90,99,102,118$, and 119, represented by yellow arrows) for gene Xa21 (Fig. 4).

In the past, several former researchers had reported introgression of various BLB resistance gene(s) into elite backgrounds using marker-assisted selection. Most of these were combinations of 3-4 genes together, followed by two and a single gene. Single gene, $X a 21$ is reported to have been successfully introgressed into Chinese hybrid rice Minghui 63 (Chen and Ronald, 1999) ${ }^{[6]}$ and Xa25 into rice transgenic cultivar, HPTER (Gao et al., 2006) ${ }^{[11]}$. Similarly Bustamam et al. (2002) reported successful pyramiding of 2 genes $(X a 4+x a 5$ and $X a 4+X a 7)$ into two rice cultivars, Angke and Conde in Indonesia. Most of these introgressions have been reported to be associated with better and durable resistance against BLB.

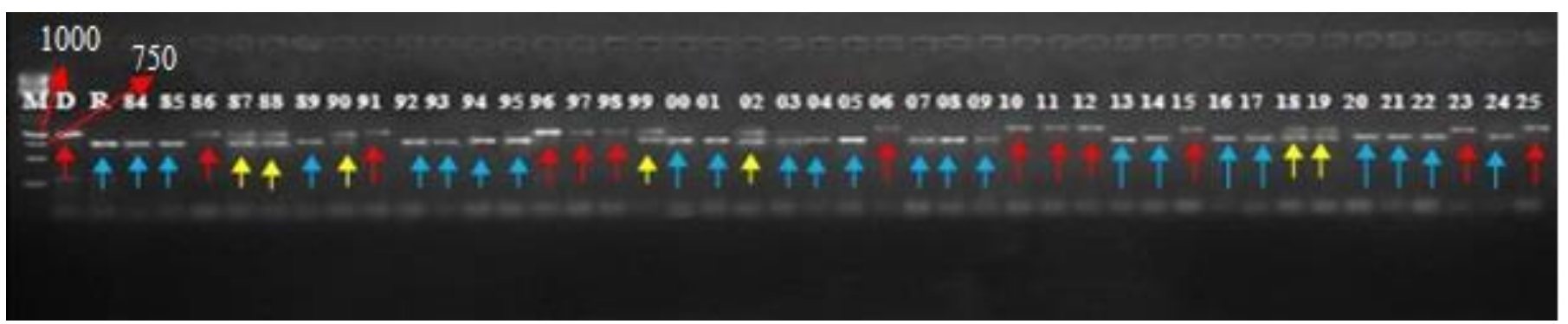

Fig 4: Foreground selection for blast resistance gene $\mathrm{Xa} 21$ in $42 \mathrm{BC}_{2} \mathrm{~F}_{2}$ progenies of cross HPR2143×IRBB54 using Blb248 Lanes in the gel from left represent M: Molecular weight marker (1kb ladder), D: recurrent parent (HPR2143), $R$ : donor parent (DHMAS164) and 84-125: $B C_{2} F_{2}$ progenies of HPR2143 X IRBB54. PCR products were resolved on 1.5 per cent Agarose and stained with ethidium bromide

\section{iv. Foreground selection for $\mathrm{Xa38}$ gene homozygotes}

In cross 4 (HPR2143 X PR114), a total of 42 plants were screened with marker $0 s 04 g$ 53050-1, out of which 6 progenies $(129,139,146,149,150$, and 153, represented by red arrows) were found to be homozygous positives and 15 $(126,128,131$ to $133,135,137,152,154,157$ to 159,163 , 165 and 166, represented by blue arrows) were inferred to be homozygous negatives. Twenty one progenies $(127,130,134$, $136,138,140$ to $145,147,148,151,155,156,160$ to 162 , 164 and 167 , represented by yellow arrows) were found to be heterozygous for gene Xa38 (Fig. 5).

Xa38, a novel BLB resistance gene was identified from Oryza nivara acc. IRGC 81825 (Cheema et al., 2008) ${ }^{[5]}$ and was mapped on chromosome $4 \mathrm{~L}$ in a $38.4 \mathrm{~kb}$ region that provided high level of resistance against multiple virulent isolates of
BLB pathogen (Bhasin et al., 2012) ${ }^{[3]}$. Precise foreground selection is the key to the success of MABB and the highly reliable marker Os04g53050-1 was used for detection of Xa38 (Bhasin et al., 2012) ${ }^{[3]}$. Since the gene is a novel one, identified and mapped recently, not many reports on its introgression and pyramiding are documented. More recently Yugander et al. (2018) ${ }^{[35]}$ have reported incorporation of the novel bacterial blight resistance gene $\mathrm{Xa38}$ into the genetic background of elite rice variety Improved Samba Mahsuri (ISM) that already possesses BLB pyramid of genes $x a 5+x a 13+X a 21$. The resultant 18 backcross-derived lines (BDLs) exhibited very high level of resistance against multiple Xoo strains and displayed agro-morphological traits, grain qualities and yield levels similar to or better than those of recurrent parent Improved Samba Mahsuri (ISM). 


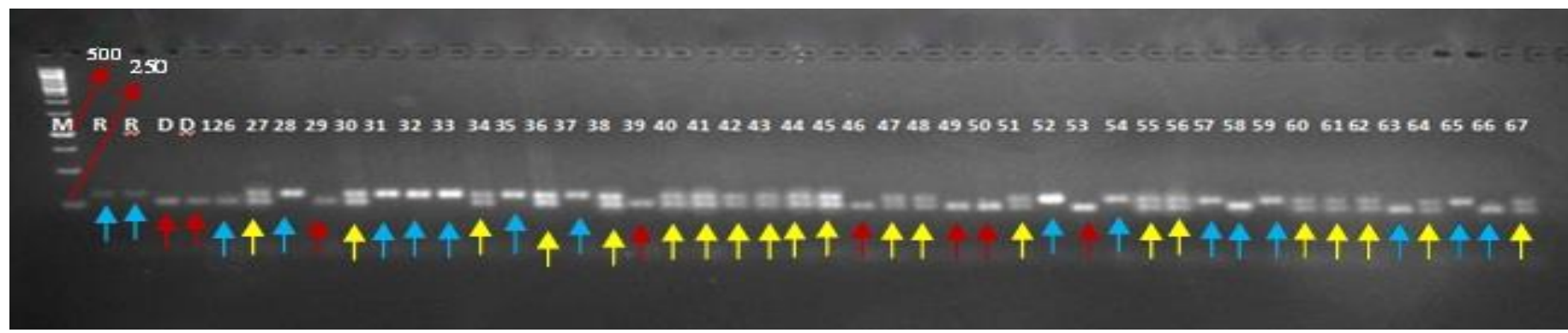

Fig 5: Foreground selection for blast resistance gene Xa38 in $42 \mathrm{BC}_{2} \mathrm{~F}_{2}$ progenies of cross HPR2143×IRBB54 using Oso4g53050-1 Lanes in the gel from left represent M: Molecular weight marker (1kb ladder), $R$ : recurrent parent (HPR2143), D: donor parent (DHMAS164) and 126-167: $B C_{2} F_{2}$ progenies of the cross, HPR2143 X PR114. PCR products were resolved on 1.5 per cent Agarose and stained with ethidium bromide

\section{v. Anther plating and callus induction}

For cross 1 (Pita $\times$ Pi9 and reciprocals), out of 22562 anthers plated on callus induction medium, 2080 calli were induced with an overall callus induction frequency of 9.21 per cent. Similarly, for cross $2(\mathrm{Xa} 21 \times \mathrm{Xa38}$ and reciprocals $) 1534$ calli were induced from a total of 16894 plated anthers with a callus induction frequency of 9.08 per cent (Table 5). Different stages of culture and callus induction in cultured anthers of $F_{1} s$ of crosses among selected backcross progenies carrying different gene combinations (Pita $\times P i 9$ and reciprocals $)$ and $(\mathrm{Xa} 21 \times \mathrm{Xa38}$ and reciprocals $)$ are shown in Plate 1.1

Table 5: Frequency of callus induction in anthers of $F_{1 s}$ of crosses among selected backcross progenies

\begin{tabular}{|c|c|c|c|}
\hline Cross & $\begin{array}{c}\text { Total number of } \\
\text { anthers plated }\end{array}$ & $\begin{array}{c}\text { Total number of } \\
\text { calli induced }\end{array}$ & $\begin{array}{c}\text { \% Callus } \\
\text { induction }\end{array}$ \\
\hline $\begin{array}{c}P i-t a \times P i-9 \text { and } \\
\text { reciprocals }\end{array}$ & 22562 & 2080 & 9.21 \\
\hline $\begin{array}{c}X a 21 \times X a 38 \text { and } \\
\text { reciprocals }\end{array}$ & 16894 & 1534 & 9.08 \\
\hline
\end{tabular}
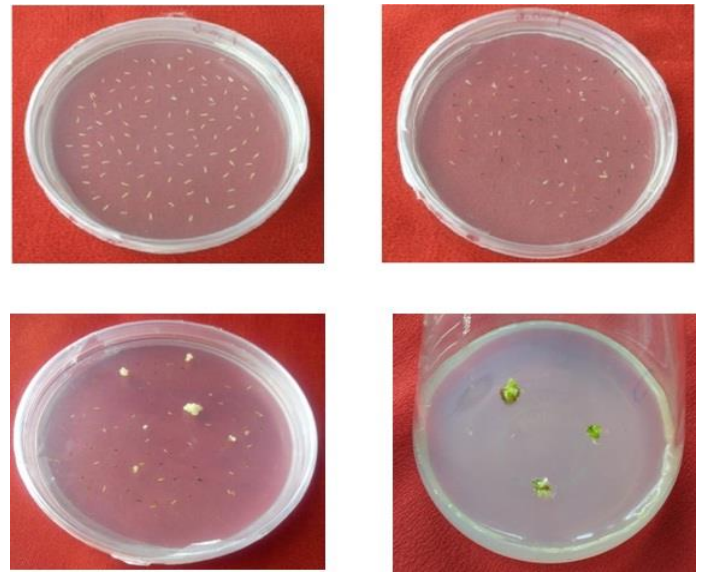

Plate 1: Different stages of anther culture and callus induction in cultured anthers of $\mathrm{F}_{1} \mathrm{~s}$ of crosses among selected backcross progenies carrying different gene combinations (Pita $\times \mathrm{Pi} 9$ and reciprocals $)$ and $(\mathrm{Xa} 21 \times \mathrm{Xa38}$ and reciprocals $)$

\section{vi. Plant regeneration from induced calli and overall anther culture response}

For cross combination 1 (Pita $+P i 9$ and reciprocals), all the induced calli (2080) were transferred to the regeneration media. Out of 1264 calli transferred, 137 calli regenerated giving rise to green and albino plantlets with an overall callus regeneration frequency of 6.5 per cent. The frequency of green plantlet regeneration recorded was $29.9 \%$ as 41 green plantlets were regenerated from 137 calli transferred on regeneration medium. However, out of total planlets regenerated, a good proportion of regenerated plantlets (96) were albino with a frequency of $70.0 \%$. The overall anther culture efficiency came out to be $0.18 \%$ as a total of 41 green plantlets regenerated from a total of 22562 anthers cultured initially (Table 6). The stages of plantlet regeneration from calli are shown in Plate 2.

Similarly, for cross 2 (Xa21 $+\mathrm{Xa} 38$ and reciprocals), all the 1534 induced calli were transferred to the regeneration media, out of which a total of 88 plantlets were regenerated, reflecting a callus regeneration frequency of 5.7 per cent. Out of total number of 88 regenerating calli, 20 were green $(22.7 \%)$ and 68 were albino $(77.2 \%)$. Hence, the overall efficiency of anther culture in $\mathrm{F}_{1}$ of cross $(\mathrm{Xa21}+\mathrm{Xa38}$ and reciprocals) was observed to be $0.11 \%$ (Table 6 ).

Overall anther culture efficiency in rice is known to be low. A significant increase in anther culture efficiency was reported in indica rice cultivars by substituting sucrose with 9.00 per cent maltose as carbon source in MO19 basal medium (Raina, 1997) ${ }^{[23]}$. Mohiuddin et al. (2014) ${ }^{[17]}$ used two types of media for plantlet regeneration through callus culture and have reported $96 \%$ green plant regeneration in BR 802-78-21-1 from KC medium whereas, only $63 \%$ was regenerated from KA medium. The frequency of albino plants was reported to be $37 \%$ from $\mathrm{KA}$ media, whereas, $4 \%$ from $\mathrm{KC}$ in the same line. The occurrence of large proportion of albino in the anther culture derived plantlets is a common feature in rice. In the present study, the frequency of albino plant regeneration varied from 70 to 77.2 per cent for cross 1 and cross 2, respectively. Several factors viz., cold pre-treatment, stage of the pollen during anther culture and culture medium is known to affect the frequency of albino. Calli regenerated from anthers at the early uninucleate stage of pollen induced only green plantlets and the frequency of albino increases with advancing stage of the pollen (Pande, 1997) ${ }^{[21]}$. High concentration of sucrose $(9 \%)$ in the culture media is also reported to lead to the high frequency of albino regeneration (Woo and Chen, 1982) ${ }^{[33] .}$

Table 6: Regeneration frequency from calli and overall anther culture response in anthers of $F_{1 s}$ of crosses among selected backcross progenies (Pita $\times P i 9$ and reciprocals) and (Xa21 $\times$ Xa38 and reciprocals)

\begin{tabular}{|c|c|c|c|c|c|c|c|}
\hline \multirow{2}{*}{ Cross } & \multicolumn{2}{|c|}{ Callus regeneration } & \multicolumn{2}{c|}{ Green plantlet regeneration } & \multicolumn{2}{c|}{ Albino plantlet regeneration } & $\begin{array}{c}\text { Anther culture } \\
\text { efficiency }(\%)\end{array}$ \\
\cline { 2 - 8 } & No. & $\%$ & No. & $\%$ & No. & $\%$ & 0.18 \\
\hline Pita $\times P i 9$ and reciprocals & 137 & 6.5 & 41 & 29.9 & 96 & 70.0 & 77.2 \\
\hline$X a 21 \times X a 38$ and reciprocals & 88 & 5.7 & 20 & 22.7 & 68 & 0.11 \\
\hline
\end{tabular}



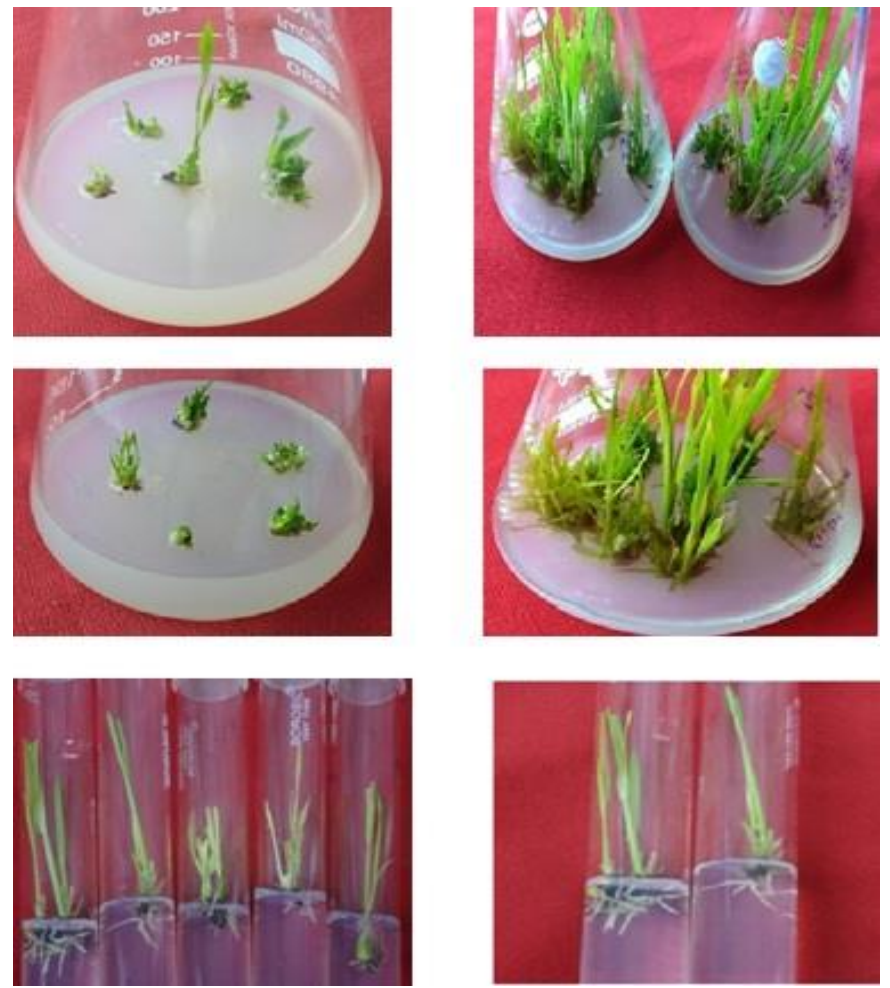

Plate 2: Plantlet regeneration from induced calli of cultured anthers of $\mathrm{F}_{1} \mathrm{~S}$ of crosses among selected backcross progenies carrying different gene combinations (Pita $\times \mathrm{Pi} 9$ and reciprocals) and (Xa21 $\times X a 38$ and reciprocals) vii. Transplantation and plantlet survival of anther culture derived plantlets

The different stages of transplantation are presented in Plate 3. Out of 41 anther culture regenerants of the cross 1 (Pita $\times$ $P i 9$ and reciprocals), 38 survived till maturity with an overall plantlet survival of 92.6 per cent. Similarly, among the regenerants of cross 2, (Pi9 $\times$ Pita and reciprocals), 19 plants survived out of 20 , with an overall survival rate of 95 per cent (Table 7). The occurrence of doubled-haploids from anther culture derived plants is a beneficial feature in rice. Both endo-reduplication and nuclear fusion have been reported to occur during rice anther culture (Segui-Simarro and Neuz, 2008) ${ }^{[28]}$ and most likely to cause spontaneous chromosome doubling in the regenerants. In the present study, 47 plants exhibited fertility and produced seeds indicating occurrence of spontaneous chromosome doubling in them.

Table 7: Plant survival of anther culture derived regenerants of $F_{1}$ 's of crosses among selected backcross progenies carrying different gene combinations (Pita $\times$ Pi9 and reciprocals) and (Xa21 $\times$ Xa38 and reciprocals)

\begin{tabular}{|c|c|c|c|}
\hline Cross & $\begin{array}{c}\text { Total } \\
\text { number of } \\
\text { plantlets } \\
\text { transferred }\end{array}$ & $\begin{array}{c}\text { Total } \\
\text { number of } \\
\text { plantlets } \\
\text { survived }\end{array}$ & $\begin{array}{c}\text { Plant } \\
\text { survival } \\
\text { frequency } \\
(\mathbf{\%})\end{array}$ \\
\hline $\begin{array}{c}\text { Pita } \times P i 9 \text { and } \\
\text { reciprocals }\end{array}$ & 41 & 38 & 92.6 \\
\hline $\begin{array}{c}X a 21 \times X a 38 \text { and } \\
\text { reciprocals }\end{array}$ & 20 & 19 & 95.0 \\
\hline
\end{tabular}
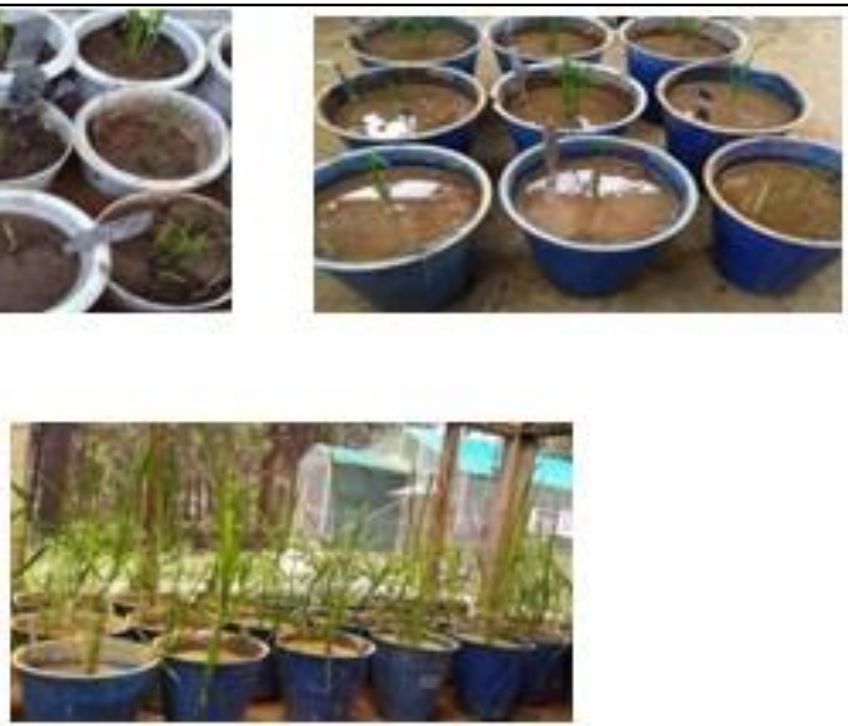

Plate 3: Stages of green plantlet transfer to polyhouse

\section{Conclusion}

Advances in DNA marker technology together with the idea of marker-assisted selection provide new elucidations for selecting and maintaining desirable genotypes. Foreground selection of $\mathrm{BC}_{2} \mathrm{~F}_{2}$ plants of two crosses (HPR2143/DHMAS164 and HPR2143/PB1) was done successfully to ascertain the presence of blast resistance genes i.e. Pita and $\mathrm{Pi} 9$ in these plants. Similarly, to detect the presence of bacterial blight resistance genes i.e. Xa2land $\mathrm{Xa38}$ in $\mathrm{BC}_{2} \mathrm{~F}_{2}$ plants of crosses (HPR2143/IRBB54 and HPR2143/PR114) foreground selection was done using gene specific markers which were reported to be successful. The study efficaciously validated the protocol developed locally in our lab for induced androgenesis in indica rice hybrids for instant fixation of derivatives while, following it in toto for fixation of two genes (Pita+Pi9 and Xa21 + Xa38) achieving moderate anther culture efficiency $(\sim 0.2 \%)$ although a high percentage of albino plantlets induction was also recorded.

\section{References}

1. Akhtar S, Bhat MA, Shafiq AW, Bhat KA, Chalkoo S, Mir MR et al. Marker assisted selection in rice. J. Phytol 2010;2(10):66-81.

2. Anonymous. Vision 2050: ICAR-Indian Institute of Rice Research, Rajendranagar, Hyderabad- 500030, Telangana, India 2015.

3. Bhasin H, Bhatia D, Raghuvanshi S, Lore JS, Sahi GK, Kaur B. New PCR based sequence-tagged site marker for bacterial blight resistance gene Xa38 of rice. Mol. Breed. 2012;30:607-611. 
4. Christopher S. Rice Today 2002;1(2):4-5.

5. Cheema KK, Grewal NK, Vikal Y, Sharma R, Lore JS, Das A et al. A novel bacterial blight resistance gene from Oryza nivara mapped to $38 \mathrm{~kb}$ region on chromosome 4L and transferred to Oryza sativa L. Genet. Res 2008;90(5):397-407.

6. Chen DH, Ronald PC. A rapid DNA mini preparation method suitable for AFLP and other PCR applications. Plant Mol. Biol. Rep. 1999;17(1):53-57.

7. Chopra M. Exploitation of biotechnological tools for management of rice blast (Magnaporthe grisea) in Himachal Pradesh. (Master dissertation), CSKHPKV, Palampur 2006.

8. Collard BCY, Mackill DJ. Marker-assisted selection: an approach for precision plant breeding in the twenty-first century. Phil. Trans. R. Soc. 2008;B363:557-572.

9. De-Filippis LF. Improvement of Crops in the era of climatic change. New York, CT: Springer 2014.

10. Fjellstrom R, McClung AM, Shank AR. SSR markers closely linked to the $P i-z$ locus are useful for selection of blast resistance in a broad array of rice germplasm. Mol. Breed 2006;17:149-157.

11. Gao DY, Guo SW, He BZ, Yan Jiao DM. Pyramiding of maize PEPC gene and bacterial blight resistance gene Xa25 in rice. Jiangsu Journal of Agricultural Sciences 2006;22(1):5-9.

12. Herawat R, Purwoko BS, Dewi IS. Characterization of doubled haploid derived from anther culture for new type upland rice. Indian Journal of Agronomy 2010;38(3):170176.

13. Khanna A, Sharma V, Ellur RK, Singh AK. Marker assisted pyramiding of major blast resistance genes Pi9 and Pita in the genetic background of an elite Basmati rice variety, Pusa Basmati 1. Indian J. Genet. Pl. Br. 2015;75(4):417-422.

14. Khush GS. Strategies for increasing the yield potential of cereals: case of rice as an example. Plant Breeding 2013;132:433-436.

15. Kim SM, Suh JP, Qin Y, Noh TH, Reinke RF, Jena KK. Identification and fine mapping of a new resistance gene, $X a 40$, conferring resistance to bacterial blight races in rice (Oryzae sativa L.) Theor. Appl. Genet 2015;128(10):1933-1943.

16. Miah G, Rafii MY, Ismail MR, Puteh AB, Rahim HA, Asfaliza R, Latif MA. Blast resistance in rice: a review of conventional breeding to molecular approaches. Mol. Biol. Rep 2013;40:2369-2388.

17. Mohiuddin AKM, Karim NH, Sultana S. Development of improved doubled-haploids through anther culture of indica rice (Oryza sativa L.). Ann. Biol Res. 2014;5(10):6-13.

18. Murray MG, Thompson WF. Rapid isolation of high molecular weight plant DNA Nucleic Acids Res 1980, 4321-4324.

19. Narayanan NN, Baisakh N, Oliva NP, Vera Cruz CM, Gnanamanickam SS, Datta K et al. Molecular breeding: marker-assisted selection combined with biolistic transformation for blast and bacterial blight resistance in indica rice (cv. CO39). Mol. Breed 2004;14:16-71.

20. Ni D, Song F, Ni J, Zhang A, Wang C, Zhao K et al. Marker-assisted selection of two-line hybrid rice for disease resistance to rice blast and bacterial blight. Field Crops Res 2015;184:1-8.
21. Pande H. Androgenesis in anther cultures of an indica cultivar of Oryza sativa L. (Doctoral Dissertation), University of Delhi, India 1997.

22. Pinta W, Toojinda T, Thummabenjapone P, Sanitchon J. Pyramiding of blast and bacterial leaf blight resistance genes into rice cultivar RD6 using marker assisted selection. Afr. J. Biotechnol. 2013;12(28):4432-4438.

23. Raina SK, Zapata FJ. Enhanced anther culture efficiency of indica rice (oryzae sativa L.) through modification of the culture media. Plant Breeding 1997;116:305-315.

24. Rathour R, Katoch A, Kusum RP, Kaushik, Sharma TR. Virulence analysis of Magnaporthe oryzae for resistance gene deployment in north-western Himalayas. Pl. Dis. Res 2011;26(2):183.

25. Rathour R, Krishnan SG, Khanna A, Dhatwalia S, Kachra A, Sharma TR et al. Development and validation of co-dominant gene based markers for $\mathrm{Pi}$, a gene governing broad-spectrum resistance against blast disease in rice. Mol. Breed 2016;36:168.

26. Ren J, Wu P, Tian X, Lübberstedt T, Chen S. QTL mapping for haploid male fertility by a segregation distortion method and fine mapping of a key QTL qhmf4 in maize. Theor. Appl. Genet 2017;130(7):1349-1359.

27. Sengsai S, Peyachoknagul S, Sripichitt P, Thongpan A, Pongtongkam $\mathrm{P}$. Anther culture of $\mathrm{BC}_{1} \mathrm{~F}_{1}$ (KDML105//IRBB5/KDML105) hybrid to produce bacterial blight resistance doubled haploids rice. Kasetsart Journal Natural Sciences 2007;41(2):251-261.

28. Seguí-Simarro JM, Nuez F. Pathways to doubled haploidy: chromosome doubling during androgenesis. Cytogenet Genome Res 2008;120:358-369.

29. Sitch LAR, Dalmacio, Romero GO. Crossability of wild Oryza species and their potential use for improvement of cultivated rice. Rice Genetics Newsletter 1989;6:58-60.

30. Sreewongchai T, Toojinda T, Thanintorn N, Kosawang C, Vanavichit A, Harreau D et al. Development of elite indica rice lines with wide spectrum of resistance to Thai blast isolates by pyramiding multiple resistance QTLs. Plant Breed 2010;129:176-180.

31. Sundaram RM, Chatterjee S, Oliva R, Laha GS, Leach JE, Sonti RV et al. Update on bacterial blight of rice: fourth international conference on bacterial blight. Rice 2014;7(7)-12.

32. Wilson RA, Talbot NJ. Under pressure: investigating the biology of plant infection by Magnaporthe oryzae. Nat. Rev. Microbiol 2009;7:185-195.

33. Woo S, Chen C. Rice anther culture in Taiwan. In: Rice Tissue Culture Planning Conference. International Rice Research. Institute, Manila. 1982, 83-90.

34. Xiao N, Huang WN, Li AH, Gao Y, Li YH, Pan $\mathrm{CH}$. Fine mapping of the qLOP2 and qPSR2-1 loci associated with chilling stress tolerance of wild rice seedlings. Therotical Genetics 2016;128:173-185.

35. Yugander A, Sundaram RM, Singh K, Ladhalakshmi D, Rao LVS, Madhav MS et al. Incorporation of the novel bacterial blight resistance gene $\mathrm{Xa38}$ into the genetic background of elite rice variety Improved Samba Mahsuri. PLoS One 2018;13(5):0198260 https://doi.org/10.1371/journal.pone.0198260 